\title{
LUXURY CONSUMPTION: a mirror of gay consumers sexual option?
}

\section{1- Joyce Gonçalves Altaf*}

Mestre em Administração e Desenvolvimento Empresarial pela Universidade Estácio de Sá (UNESA), Brasil.

Coordenadora dos cursos de graduação em Administração de Empresas e Ciências Econômicas das Faculdades Integradas do Instituto Vianna Júnior, Brasil.

jgaltaf@yahoo.com.br

http://lattes.cnpq.br/4729992860551883

\section{2- Irene Raguenet Troccoli}

Doutora em Administração de Empresas pela Pontifícia Universidade Católica do Rio de Janeiro (PUC-Rio), Brasil. Professora do Mestrado Acadêmico em Administração e Desenvolvimento Empresarial da Universidade Estácio de Sá (UNESA), Brasil.

irene.troccoli@estacio.br

http://lattes.cnpq.br/4098098876460779

\section{3- Christiane Bara Paschoalino}

Mestre em Marketing/Management in Global IT pela American University (AU), EUA.

Professora do curso de Administração de Empresas das Faculdades Integradas do Instituto Vianna Júnior / Fundação Getúlio Vargas (FGV), Brasil.

chrica@gmail.com

http://lattes.cnpq.br/4850164276942749

\section{4- Maria Angélica Luqueze}

Doutoranda em Finanças pela Pontifícia Universidade Católica do Rio de Janeiro (PUC-Rio), Brasil. angelica-luqueze@puc-rio.br

http://lattes.cnpq.br/7311381406023469

Diego Maganhotto Coraiola - Editor 


\section{LUXURY CLOTHING: A MIRROR OF GAY CONSUMERS SEXUAL OPTION?}

\section{ABSTRACT}

Through a qualitative exploratory research, the present paper investigates the behaviour of Brazilian gay consumers as to their luxury clothing consumption, assuming that this behaviour might help the construction of their self-concept once those products reflect their sexual option. A bibliographical review is followed by the results for in-depth interviews with 12 gay men, and completed with the use of a semantic scale that measures the interviewees' self-concept and luxury clothing concept. An examination of the results is followed by their implications, indicating that the self-concept directly influences the male gay's buying behaviour in this market.

\section{Keywords}

Gay consumers; Luxury clothing consumption; Self-concept construction; Buying behaviour. 


\section{Introduction}

Consumption is a continuous process. It goes beyond exchanging money for goods or services. It involves matters that affect consumers before, during and after purchasing. It also influences the whole process of searching, choosing and making the decision to buy a product, as well as the experience during consumption, post-consumption product performance and the consequences of that purchase (Hirschman \& Holbrook, 1982).

When talking about consumption, it is necessary not only to consider tangible objects but also the experiences, ideas and intangible characteristics (Solomon, 2002). According to Holbrook, Block and Fitzsimmons (1996), many consumption experiences such as fantasies, feelings, and fun are behind the buying decisions and need to be considered in order to understand the consumption phenomenon. Depending on what one buys, consumption may be much more a symbolic than an economic act, according to (Rocha, 1995), and "[ ...] is the virtual totality of all objects and messages organized in a much more coherent speech. It is an activity involving the systematic manipulation of signs" (Baudrillard, 1973, p. 66).

Over time, products that are not commodities are no longer differentiated by their intrinsic features. Now, their differentiation occurs through the symbolic assigned to them and to their brands (Rocha, 1995). From the moment that the object begins to mean more them just its materiality, it achieves the character of a sign, acquiring coherence and meaning in an abstract relationship with other object-signs (Baudrillard, 1973). Therefore, the consumed objects acquired a differentiation value among individuals.

The domain of consumption takes place when people/men and objects are brought into contact, acquiring sense, creating meanings and social distinctions (Rocha, 1984). And the sociology of difference translates into an objective social demand for signs and differences, a dimension no longer grounding consumption as a function of individual satisfaction, but as a social activity (Baudrillard, 1981). In regard to the symbolism and meanings of consumption, products are a valuable source of information about its consumers (Belk, 1988).

At the same time, consumer choices are made by a variety of reasons which are not that easy to predict and understand (Campos, Suarez \& Casotti, 2005). However, frequently, consumers not only rely on the social meaning of products to shape their self-image (Solomon, 1983), but also reveal their personality through the consumption of custom-made products (McCracken, 1986).

In this context it becomes interesting to study the behaviour of the modern gay consumer, whose emergence of identity was fostered by socio-economic and psychological conditions generated by capitalism (Nunan, 2003). This allowed gays, among others individuals who avoid the standards traditionally accepted by society, to feel free to express their identity through the use of products and services. Additionally, it led the market oriented to the fulfillment of these specific needs to become one of the foundations of this subculture of consumption, defined by Hawkins, Mothrsbaugh and Best (2007, p. 73) as “[ ... a distinct subgroup of society whose members select themselves based on shared commitment in relation to a consumer class, brand, or specific consumption activity".

This article is divided into eight parts, with this introduction being the first one. The second part contains information about the male gay consumer market, emphasizing its economic potential and some specific behavioural characteristics. In the third section, we present definitions and measurements of the luxury products market. The fourth part exposes the construct of self-concept, and the fifth the connection between self-concept and the consumption of luxury brand products. The sixth part describes the methodology employed, and the seventh the results of a research conducted with 12 subjects, representatives of this subculture, in regard to their perception about self-concept and their concept about luxury consumption. Finally, the eighth part presents the conclusions that the self-concept directly influences the male gay buying behaviour.

\section{The Luxury Market}

Defining luxury product is not a simple task. After all, this is a relative concept - what is luxury for some can be just ordinary for others. Thus, both the term's definition and the choice of products are variable, according to the socioeconomic class of each individual, associated with psychological aspects such as motivation and lifestyle. There is a an agreed convention in the business administration and marketing fields to define luxury as a product or service that provides quality, aesthetics, price and brand image superior than the conventional products and services. They may belong to several categories of products, 
although some of them are, of course, more suitable to the concept (D'Angelo, 2004), such as jewelry, clothing, accessories and luxury cars. Following the contributions made by several authors, including Castarède (2005), Allérès (2000), Haie (2002), Lipovetsky and Roux (2005) and Baudrillard (1981), herein, the concept of luxury will not only be restricted to social class, but will also consider other characteristics. For some, luxury means something expensive and non-democratic, to which access is restricted.

However, the definition of the term is not limited to that. After all, according to Castarède (2005, p. 24), "Luxury is what is unusual and related to talent, elegance, magnificence and celebration. It is everything that is not necessary". In addition to that, he adds that "Luxury products are not banalized and carry with them an aura of dream, an immaterial connotation. Their price is related to the scarcity criteria that they represent". As for Allérès (2000), luxury is what best corresponds to the expression of desires and human emotions in a way that it becomes possible to learn about the universe of people who consume it. In this universe, it is presumed that objects are a part - important and highly representative because they are intangible - of a system of values and of a shared view of the world that give them meaning. Haie (2002) states that the authentic luxury emphasizes "being" more than "having", evidencing individuality according to castes and social layers.

Therefore, what the individual seeks in luxury is a way to express and differentiate his social self, and not only to demonstrate his social position. Two points of view regarding luxury are defined by Castarède (2005). The first one belongs to the purists who consider luxury as a type of consumption of high investment, classifying these products as assets. In the second, luxury is a superfluous, a synonym of futility and totally unnecessary. D'Angelo (2004, p.40) highlights the features of these products as being expensive (higher price compared with products of similar functionality), providing superior quality (technology employed, exceptional raw material and often handmade products), rare (exclusively produced and distributed in a selective and restricted way), aesthetically well-designed (having a particular appearance, which leads to emotional and hedonic consumption), associated with a famous brand (wellknown brand image in many countries around the world), purchased by specific consumers (due to their ability to appreciate the product or just because of their high purchasing power), and "snob" (they can rely on small groups of "opinion leaders" who will promote the product).

The combination of these elements provides the luxury image to a product, creating the imaginary and the glamour that surround the object, something essential to the perpetuation of its image. According to Allérès (2000), luxury products have four main categories (dimensions): functional (refers to utility in the strict sense), cultural (represented by the history of the product or its creator), symbolic (linked to the narcissism and hedonism of the object's consumption) and social (evidenced by the stimulation of desires for distinction and imitation).

Furthermore, there are nuances that differentiate one luxury object from another. For D'Angelo (2004), there is the inaccessible luxury (seen as an asset that can be passed down through many generations of the same family; for instance: jewelry, yachts), the intermediate luxury (objects produced in small amounts; for instance: prêt-à-porter) and the accessible luxury (focused primarily on quality and well-being, satisfying the hedonic demands of the individual; for instance: perfumes).

Lipovetsky and Roux (2005) agree that nowadays luxury is no longer limited to only a small portion of the population with high purchasing power. It is also accessible to others who wish to enjoy it and have a minimum financial capacity to buy this type of product. Hence, one can conclude that there is a connection between the luxury goods categories and its use by different social strata.

Not surprisingly, therefore, that according to Allérès (2000), the intermediate and middle social classes have joined the so-called wealthy class in the consumption of luxury goods, although each of them follows specific consumption patterns and belongs to different luxury categories - respectively, intermediate luxury, accessible luxury and inaccessible luxury. D'Angelo (2004) suggests another aspect of luxury goods consumption, concerning the flexibility in the payment methods. In Brazil, the payment in installments (usually via credit card) has contributed to the change in the luxury consumer profile. Prior to the availability of this payment method, there was not a transitory situation in the luxury consumption. There were only two options: to be a luxury consumer or not to be. 


\section{The Self-Concept}

Despite the importance of the "builders" elements of the luxury market, it is important to not forget that this type of market is supported by elements which are much more abstract than the idealization and materialization of a product differentiated from others in the same category. In other words, these products, in addition to their objective and subjective qualities, represented respectively by their functionality and aesthetics, have a symbolic dimension that needs to be considered (Allérès, 2000). More than any other product, luxury items are bought not for what they are, but for what they mean (Amui, 2006).

For this reason, in order to explain the concept, Vigneron and Johnson (2004) gathered the meanings that are present in the luxury consumption in five dimensions, including the extended "self". In this particular, Hawkins et al (2007) explain that some products acquire substantial meaning for an individual or are used to indicate particularly important aspects of the personality of that person to others. This remark refers to the Extended Self Theory, by Belk (1988), which consists in adding the possessions to the "self": people would define themselves, partly, through their possessions.

This theory is supported by the idea that possessions would be more than just a manifestation of a person's self-image, reaching the point of being an integral part of their self-identity. This self-identity (or self-concept) is in turn defined by Hawkins et al. (2007, p. 228) as "...'the totality of the individual's thoughts and feelings having referencing himself as an object". The self-concept and the "self" have been widely studied as much by psychology as by marketing - in the latter case, more specifically in the consumer behaviour area - due to the effectiveness of both constructs for further study about the motivations concerning the consumption of goods and services.

Although Cavallet-Mengarelli $(2008$, p. 32) asserts that the terms self-concept and self "[ ...] are often mistaken for one another in certain studies and approaches", they can be understood in different ways. Thus, for Doron and Parot (1998, p. 12), self-concept would be "[ ...] a representation of the self in the knowledge system of the individual", whereas "self' would refer to a broader perception, "[ ...] what defines a person as a whole" (p. 34).

Corroborating this view, Cavallet-Mengarelli $(2008$, p.22) emphasizes that "self" is the person while a place of psychic activity in its totality". Psychology presents the construct of self-concept from different theoretical premises, summarized and contextualized by Reed II (2002), who states that any paradigm of self-concept begins with the definition of the construct, which allows an evaluation of its dimensions, and the determination of where it resides. These paradigms answer questions such as whether the self-concept is related to more introspective structures of the individual - thoughts, beliefs and attitudes - or to individual interactions of that person in the social network.

As for Miranda (1998), the self-knowledge theories can be classified into six types, according to their respective ways of seeing the construct: psychoanalytic (a system marked by conflicts), behavioural (a set of conditioned responses), organic (in terms of development and functionality), phenomenological (from the point of view of the individual in a holistic way), cognitive (a conceptual system of information processing) and social (as a function of social interactions). It is this latter, together with the cognitive definition - that according to Miranda (1998, p. 27), "[ ...] focuses on the process by which individuals interpret the actions of others and then choose the most appropriate way to expose themselves to society" - that will be used in this article. It is important to notice that the self-concept has been investigated by several fields and based on multiple interpretations.

Although the research about self-concept in the study of consumer behaviour is presented in a fragmented and diffuse manner (Sirgy, 1982; Reed II, 2002), the perception that the consumer is not only oriented by functional aspects, but is also significantly affected by symbolic aspects, stimulated the study of this construct in relation to consumer behaviour (Sirgy, 1982). The self-concept can be represented as the way in which an individual sees himself: the "who am I?". Sirgy (1982) conducted a comprehensive critical theoretical review of researches related to self-concept. According to him, the self-concept, in general, has been defined by marketing research as [ ...] the totality of the individual's thoughts and feelings having referencing himself as an object" (Hawkins et al., 2007, p. 229).

In parallel, Belk (1988) suggested that the individual's possessions are part of his identity, when observing the relationship between these possessions and the human beings' sense of self. This relationship is analyzed as a two-way road: "We may impose our identities on possessions and possessions may impose their identities on us" (Belk, 1988, p. 141). A person may represent his "self" through a variety 
of factors, such as his ideas, money, pets, collections, other people and body parts. The way a person relates to these objects can also reveal much of the subjective structure of the consumer - that is why the loss of possessions, in many cases, is perceived by the individual as a loss of a part of himself. This is justified because human beings invest parts of their "selves" in the objects (Belk, 1988). More than all the trouble to buy the objects, they invest psychological energies, devoting effort, time and attention.

The study of self-concept in the marketing and consumer behaviour fields sought, in many cases, to draw parallels between the individual's self-concept and the image of the product consumed. The greater the visibility, personality and variability of the product, the greater the possibility of communication of selfconcept through it, and, therefore, consumption becomes more symbolic. Sirgy (1982) gathered some important contributions to the self-concept theory, including the assertion by Grubb and Grathwohl (1967) that products communicate symbolic meanings and that the individual's behaviour is directed toward the enhancement and protection of the self-concept. Schenk and Holman (1980) introduced an important perspective that replaced the proliferation of concepts and included a behavioural component. It is an approach that considers the self-concept as a unique situation, in which the individual chooses the "self" he will express, according to the characteristics of the moment or of the group to which he belongs.

When related to product images, the self-concept is being addressed by several approaches: the relationship between the product image with a stereotyped image of the user or with the self-concept. In this sense, it is important to emphasize the theory of self-concept and product image congruity, by Sirgy (1982): consumers generally seek products and brands that are compatible with their identities, therefore, products that convey a certain image - for instance, social status - can activate similar benefits for the person. The same author states that most of the studies conducted in this area have been based on the perspective that consumers are motivated to approach products that match their self-perceptions.

According to Sirgy's (1982) congruity theory, the perceived value of self-image (positive or negative) interacts with the perceived value of product image (positive or negative). The self-esteem demands products that increase the self-image value, and the self-consistency products that do not conflict with the self-image and that act as mediating factors. Sirgy (1982) also exposes the global self-attitude concept, which includes self-esteem and self-satisfaction and has been treated as a conscious judgment regarding the relationship of one's actual self to the ideal or social self.

This definition makes it clear that the individual not only compares his actual self-concept with what he would like to be, but also compares his self-concept with his perceptions about other people in his social group. By comparing these concepts to the luxury universe, it is important to consider consumption as a means of construction of the individual's identity. Commonly, the consumer adopts a buying behaviour that is consistent with the lifestyle of the upper classes and rejects what resembles the lower classes (Vigneron \& Johnson, 2004).

According to Belk (1988), the concept o materialism becomes relevant because the identity - being abstract - needs to be evidenced through concrete aspects which are, primarily, what we do and what we have. For Richins (1991, p.28), "Materialistic consumers may perceive luxury consumption as a means of achieving happiness and may use this same criteria to evaluate their and other people's success.

Corroborating this view, Belk (1988) emphasizes that, although there is no positive relationship between materialism and happiness, it is extremely important that luxury products be represented to look as if they were the individual's reason for living. Belk (1988) also points out that attributes such as possessiveness, jealousy and lack of generosity bring a very negative connotation to materialism. The author also highlights that having the same brands, goals and consumption styles provide contemporary society with a sense of community that would not exist without consumption.

On the other hand, Twitchell $(2000$, p.8) has a more positive view of materialism: "Buying stuff is not just our current popular culture, it is how we understand the world". Csikszentmihalyi (2000) states that, to some extent, material resources contribute to quality of life, and the human being has a need to feel part of a group and be accepted by its members.

However, many times, he may not be able to play the role he would like. In situations where the social role is a new experience for the individual, the decision to choose a product will depend on the stereotyped impression of the role. For instance, the "new riches" demonstrate their status through the wasteful and lavish consumption, whereas the "old riches" depend less on products to be able to play this role (Solomon, 1983). Thus, a significant portion of consumer behaviour is, indeed, social behaviour. 


\section{Association Between Self-Concept and the Consumption of Luxury Brand Products}

The associations of individuals to certain brands derive from the use of such brands by reference groups. As the symbolic properties of the group are attached to brands, and people use them, these associations are transferred to the consumer as an individual. The acceptance level of interpersonal influences depends on the level of independence or interdependence in the construction of the individual's self. Independence is a characteristic that can vary culturally and from individual to individual. "Individuals use brands to create and communicate their self-concept, thereby creating connections between the "self" and the brand" (Chaplin \& John, 2005).

Consumers can appropriate the associations belonging to brands, such as user characteristics or personality traits, and incorporate them into their self-concepts. In doing so, consumers form connections between brands and their self-concepts, referred as self-brand connections (Chaplin \& John, 2005), which are formed when consumers engage in a matching process to identify products or brands that are congruent with their self-images. Escalas and Bettman (2005a) state that people select brands that maximize similarity to their actual or desired self-concept, thereby creating a self-brand connection. In other words, the brand choices are based on finding the congruence between the user's stereotyped image and the consumer's self-image (Escalas \& Bettman, 2005b).

In referring specifically to the luxury brands, consumer expectations become ever more complex. These products, in addition to objective and subjective qualities, respectively represented by functionality and aesthetics, have a symbolic dimension that needs to be considered (Allérès, 2000). More than any other product, the items are bought not for what they are, but for what they mean (Amui, 2006). As stated by Allérès (2000), there are four distinct roles that a product can perform: functional, cultural, symbolic and social. Nevertheless, due to the great importance of understanding what motivates consumers to purchase luxury products, it is necessary to present the definition proposed by Vigneron and Johnson (2004).

In order to explain the concept, the authors gathered the meanings of luxury consumption in five dimensions:

1) Conspicuousness: reflects a search for representations or social position through exhibition and ostentatious consumption. According to Solomon (2002), many consumers like to feel special, rich, self-fulfilled and even famous. And they have the need to buy products not only to be appreciated but also to communicate their affluence to others. Veblen (1899) explains that this phenomenon is closely linked to the lifestyle of the leisure class;

2) Uniqueness: refers to products that are limited in supply or scarce. It influences brand choices as luxury consumers enjoy exclusivity (Vigneron \& Johnson, 2004). According to Amui (2006), when consumers buy a luxury product, it must be unique in some way so that it will make them be different from others. The more expensive the product is, the greater the desire for uniqueness (Vigneron \& Johnson, 2004). The distinct consumption patterns range from objects to the development of social and cultural activities. Bourdieu (1981), based on the concept of intellectual capital, explains that there are some practices acquired by individuals that are exclusivist and socially rare and, therefore, considered a differentiating factor between individuals;

3) Quality: this is something necessary for luxury products, which need to have superior quality if compared to other products or, at least, seem to have it (Vigneron \& Johnson, 2004). Amui (2006) emphasizes that quality can be perceived based on features such as differentiated design and functional superiority, advanced technology and sophisticated engineering;

4) Hedonism: it is the dimension transmitted by luxury consumption when consumers are looking for pleasure, reward and personal fulfillment by purchasing a certain product. It is a feeling that is stimulated much more by the subjective emotional benefits than by the functional benefits of the object (Vigneron \& Johnson, 2004);

5) Extended self: in the universe of luxury, consumption as a construction of the individual's identity is also very important. Commonly, the consumer adopts a buying behaviour that is consistent with the lifestyle of the upper classes and rejects what resembles the lower classes (Vigneron \& Johnson, 2004).

The world of consumers can be divided into smaller parts, gathering, in the same group, individuals with similar characteristics. According to Solomon (2002), demographic statistics are the most common type of segmentation, measuring observable aspects of a population such as age, gender or income. Thus, 
analyzing the behaviour of social groups would be an adequate approach to investigate symbolic consumer behaviour (Hirschman, 1986). The understanding of consumption as an important part of the construction and maintenance of our identities is used to acknowledge human beings as social beings (Slater, 2002; Wattanasuwan, 2005).

Furthermore, consumption can also be used as an instrument for social classification (Bourdieu, 1983), identity construction (Belk, 1988; Slater, 2002; Kates, 1998), and resistance to social exclusion and discrimination (Kates, 1998). Thereby, the consumption behaviour provides a greater understanding about the behaviour of individuals who seek to be part of a group, as in the case of male gays.

\section{Male Gay Consumer Market}

The study of the gay consumer market - and not only its male portion - proves to be relevant if the size of this niche is taken into account in economic terms. As of its 2007 census, the Brazilian Institute of Geography and Statistics (IBGE) included a question about the interviewees' sexual orientation. As a result, it was estimated that $10 \%$ of the Brazilian population is made up of gays, representing somewhere around 18 million people. This is a significant number taking into consideration the negligence on the part of public agencies and business entities in regard to a deeper knowledge about the Brazilian gay (Constâncio, 2007).

In other words, in spite of its size in population terms, a few researches about the composition or preferences of the national gay public have been conducted in Brazil in order to identify its profile. Not to mention that most of the researches are not developed by "official" research agencies and are restricted to the universe and the respective researched public: each one is performed in different environments and situations, such as websites for gays, lesbians and sympathizers - GLS, or during public manifestations, such as parades organized by groups of gays, lesbians, bisexuals and transsexuals - GLBT. According to Constâncio (2007), in spite of these restrictions, it is possible to obtain an approximated profile of the Brazilian gay public through the similarity of the data collected from each of these isolated researches.

Thus, in the absence of data for the country as a whole, the results of a research conducted in Sao Paulo in 2007 by Paulista University, ordered by SPTuris ${ }^{1}$ (SPTuris, 2007), illustrated this profile: $34 \%$ of the gays belong to the A class, $50 \%$ to the $\mathrm{B}$ class, and $16 \%$ to the $\mathrm{C}$ class; $92 \%$ are likely to travel frequently; $63 \%$ subscribe to a major newspaper; $91 \%$ read magazines; and 31\% claimed to have credit card.

Another research, ordered by the Ministry of Health in 2003 to the Brazilian Institute of Public Opinion and Statistics (IBOPE), outlined the gay segment profile, based on 1,200 interviews conducted during the three largest gay parades in Brazil - in São Paulo, in Rio de Janeiro and in Salvador: $57 \%$ were white, $11 \%$ black and $32 \%$ mulattos; $48 \%$ belonged to the $\mathrm{A} / \mathrm{B}$ social classes, $35 \%$ to the $\mathrm{C}$ class and $18 \%$ to the D/E classes; $47 \%$ were up to 24 years old and $53 \%$ were over 24 years old; $16 \%$ had finished the 8 th grade of elementary school, $48 \%$ high school and $35 \%$ had a higher education degree; $15 \%$ had monthly income up to two minimum wages, $27 \%$ more than two and up to five minimum wages, $23 \%$ more than five and up to 10 minimum wages, and $20 \%$ more than 10 and up to 20 minimum wages; $60 \%$ worked full-time, $20 \%$ part-time and $19 \%$ did not work.

Therefore, the data allow us to conclude that the gays who reveal their sexual orientation could represent not only a significant portion of the Brazilian population, but also be a relevant contingent with high consumption power and above average educational level, representing an important consumer niche. Also according to these researches, gay consumers have a specific profile: they are demanding and often establish relationship with brands or products only if there is an aggregate social value.

Moreover, in spite of the recent advances in the gay rights concerning children adoption, most of the Brazilian gay couples do not have children. Hence, they would have more income available for immediate consumption. Thus, the differential that drives gay consumers is that they demand long-lasting quality products or services - theoretically with high value. However, it is worth remembering that this conclusion should be considered cautiously. That is because although several studies about the number of gay individuals have been conducted, only a few are reliable.

There are three reasons for questioning the reliability of these researches: first of all, due to the fear of prejudice and stigmatization, it is possible that, even when responding anonymously, many subjects do not reveal their true sexual orientation or tend to lie about aspects related do it, thus inferring that the number of gays would be higher than the one revealed in the researches. Secondly, it can be implied that the 
number of gays who reveal their sexual orientation is greater among those who have higher education, given their capacity to easily accept their sexual option, which would suggest that the results of censuses and surveys related to this subculture would be naturally biased. Finally, the criteria to define what a gay is vary according to the characteristics of each study.

In spite of these restrictions, understanding what leads this market niche to purchase a particular type of product category is undoubtedly of major importance for organizations which intend to work with clients distinguished by their attractive attributes as consumers.

One of the first information referring to this matter was addressed by Soares (2000): despite social class, gays care much more about image, appearance and fashion than heterosexuals, regardless of their clothing style - some gays would dress in a "classic" way while others would prefer an "extravagant" look. When considering consumption patterns, Nunan (2003) emphasizes that gays and lesbians would spend more than heterosexuals on items such as travel, cars, credit cards, restaurants, clothing, perfume and electronics, among others products. In addition to that, the same author highlights that, compared to the heterosexual population, these consumers would also be younger, social and politically more knowledgeable, more concerned about fashion and more loyal to certain brands.

In conclusion, she adds that friendship is very meaningful to gays and, for this reason, they enjoy giving gifts to their loved ones - which increases their potential for consumption and, as a result, they become an even more attractive segment for marketing.

Other authors (Bowes, 1996; Delozier \& Rodrigues, 1996) added that many gays are self-employed and concerned about their physical and psychological well-being, which would suggest that they are open for new technologies. The survey conducted by the market research firm Ipsos Marplan (2006) corroborates this assumption: according to the study, in 2006, among the total Brazilian population, the gays had the highest ownership rates of cell phones, digital cameras, computers and notebooks.

Supporting the behavioural peculiarities of this subculture, Lukenbill (1999) identified five areas in which consumers, who self-identified as gays, differ from heterosexual consumers: they are more individualistic, have a high need to join with other people (due to the social isolation that they constantly bear), seek new life experiences in order to try to distance themselves from the daily routine, and need to relieve high levels of stress.

\section{Methodology}

The subjects of the research consisted of 12 Brazilian men who disclose their gay identity, selected based on one predetermined criterium (Gaskell, 2004) in order to achieve greater uniformity: only men with a minimum income of $\mathrm{R} \$ 6,000$ monthly ${ }^{2}$ obtained from activities not related to the work as transsexuals, transvestites and drag queens.

In order to measure their self-concept (that is, their self-image) and their concept regarding luxury, a specific item was chosen: luxury clothing. Following this, they were subjected to in-depth interviews as well as to the application of the 7-point semantic differential scale. This scale was inspired by the proposals of Ross (1971) and Malhotra (1981), which were merged and adjusted based on the results from the application of a pre-test, when the subjects questioned about certain adjectives employed. It contained 16 pairs of two bipolar adjectives each: Rough/Delicate, Agitated/Calm, Informed/Uninformed, Dominant/Submissive, Economical/Wasteful, Pleasant/Unpleasant, Contemporary/Traditional, Organized/Disorganized, Rational/Emotional, Young/Mature, Formal/Informal, Conservative/Liberal, Complex/Simple, Colorless/Colorful, Weak/Strong, Modest/Vain.

The interviewees used the scale twice: 1 ) registering at the point of each one that had more to do with the "ideal self" of the interviewee, that is, the type of person they would most like to be or how they would like to see themselves; 2) registering at the point which would best describe the type of gay that, in the opinion of the interviewee, would most like to use the brand considered as favourite.

The data thus obtained was treated based on Ross (1971), following four steps:

1) to each of the seven non-numbered levels of the 16 options in semantic scale was assigned a value, from 1 (corresponding to the nearest point of the adjective on the left) to 7 (corresponding to the closest point of the adjective on the right); 
2) the simple arithmetic mean was calculated for the responses of all interviewees, for each of the16 bipolar adjectives options, separately in order to measure the interviewee's self-concept as well as his concept about luxury clothing;

3) the means of each of the semantic scale options for both cases were plotted in six Excel graphs. Herein, it is worth recalling the proposition of Sivadas and Machleit (1994) proposition which implies that the closer the result is to the unity, the greater the concordance on this incorporation, and viceversa: the closer to 7, the greater the discrepancy. Being the central point on the scale, the point 4 can be considered as the interviewee's point of indifference regarding the proposed statement;

4) a radar type graphic was constructed do present the means, for all respondents, of each one of the semantic scale options for the mediation of self-concept and the concept about luxury clothing. Hereby, the aim was to enrich the understanding of the interviewees' perceptions in two ways: 1) verifying whether there was - or not - convergence between both perceptions on the part of the interviewees; and 2) confronting the points of view obtained through the application of this scale that, for the same interviewee, were conflicting with those obtained from the analysis of the free discourse presented at the interview.

The content of the 12 interviews conducted was carefully analyzed, following the discourse analysis methodology principle. The approach of the discourse analysis herein considered has its origins in France and has been adopted by many scholars such as Faria and Linhares (1993) and Carrieri and Sarsur (2002). This approach is based on the assumption that discourse involves both intra and interdiscoursive levels which allow the comprehension of its totality, since there is a relationship of interdependence and complementarity between these two dimensions (Faria, 2001). The study of the discursive strategies of persuasion provides a path for this comprehension because this type of study will lead to a better understanding of the dynamic and procedural relationship between the intra and interdiscourse (Kubo, 2003).

Moreover, the study of persuasion strategies clarifies the understanding of ideologies, since they are constantly reified, transformed or abandoned through argumentation. This technique allowed a careful analysis on the descriptions of each of the interviewees, focusing on the search for units of meaning and on the transcription of the most relevant segments of the interviews which relate the self-concept to a construct that affects the behaviour of the luxury goods consumer.

\section{Results}

Figure 1 - which presents the means, for all respondents, of each one of the semantic scale options for the mediation of self-concept and the concept about luxury clothing - aims to give immediate visibility on the congruence (or incongruity) between both perceptions, as well as on the intensities of closeness or deviation.

One can see that the means of self-concept and of the concept about luxury clothing were very close to each other in the case of the bipolar adjectives pair \# 3 (informed/uninformed), 14 (colorless/colorful), 15 (weak/strong) and 12 (conservative/liberal) Among these pairs, number 3 (informed / uninformed) was the one which had the highest degree of closeness. Most interviewees' discourse supports this, having been stressed that they care very much for information, and that the way you dress yourself has to do with this: "My job requires me to be trendy" (Interviewee \# 6).

The second item which presented the highest closeness degree was \# 14 (colorless/colorful), when most of the interviewees highlighted that they enjoy being "colorful", having associated color with joy or brightness, and wearing a particular clothing brand as a way to obtain these features:

When I wear Nike I feel strong, handsome and powerful. The brand enlightens me (Interviewee \# 5).

The third pair with the highest closeness degree was item 15, which corresponds to adjectives "weak" and "strong"; here it was observed that many interviewees interpret brands which they consider as "very masculine" in order to achieve power: "ll love men who look like men. This travestite thing doesn't please me". (Interviewee \# 6).

The last pair of adjectives with higher closeness was the number 12 (conservative and liberal), where most of the interviewees identified themselves as being liberal regarding the way of dressing: 
I used to be super consumerist and liked to buy whatever was fashionable. Not any more. I think that, being 44 years old and having had a full life (laughters) I don't need this any more. I dress the way I want, I have no commitment to anything. I am a liberal person, I wear whatever I want. (Interviewee \# 5)

As for the adjectives pairs with lower congruences between self-concept and clothing concept, item 5 is to be stressed, related to the economical/wasteful adjectives. In this respect, the score for the self-concept in the semantic scale was 2.75 in the average of all respondents - that is, closer to the economical adjective. However, the discourse analysis showed that most interviewees feel that they spend too much and would like to be more economical while, at the same time, they referred to their favourite brands as being less accessible. This paradox can be readily observed when they point out that they enjoy exclusivity, a feature that usually raises the price of the piece:

I am completely crazy for brands. I used to buy wildly, spending on the limits of my credit card... Nowadays I am a little bit more responsible (laughters) (Interviewee \# 8).

In regard to the second adjective pair (agitated/calm), it also presented divergence between selfconcept and clothing concept. This may be due to the difficulty the interviewees demonstrate in associating their clothes specifically to this type of behaviour:

I really don't understand how I am to classify the brand Forum as agitated or calm... This question is a little strange. How would you classify it? (Interviewee \# 3).

Another pair of adjectives which presented a paradoxical view was item 1 (rough/delicate), since most of the respondents revealed that they would like to be seen as delicate although they would prefer brands considered as rough:

I don't like gay brands like Calvin Klein because they show the body too much. In my opinion, a man must dress like a man. My husband loves CK, but I don't let him wear it (laughters), I think it's simply ridiculous. If he insits, I let him, but I don't like. The only really gay thing I love are sunglasses. Sunglasses for straight men are horrible. My face is large, I would look weird with a straight guy's sunglasses. (Interviewee \# 7)

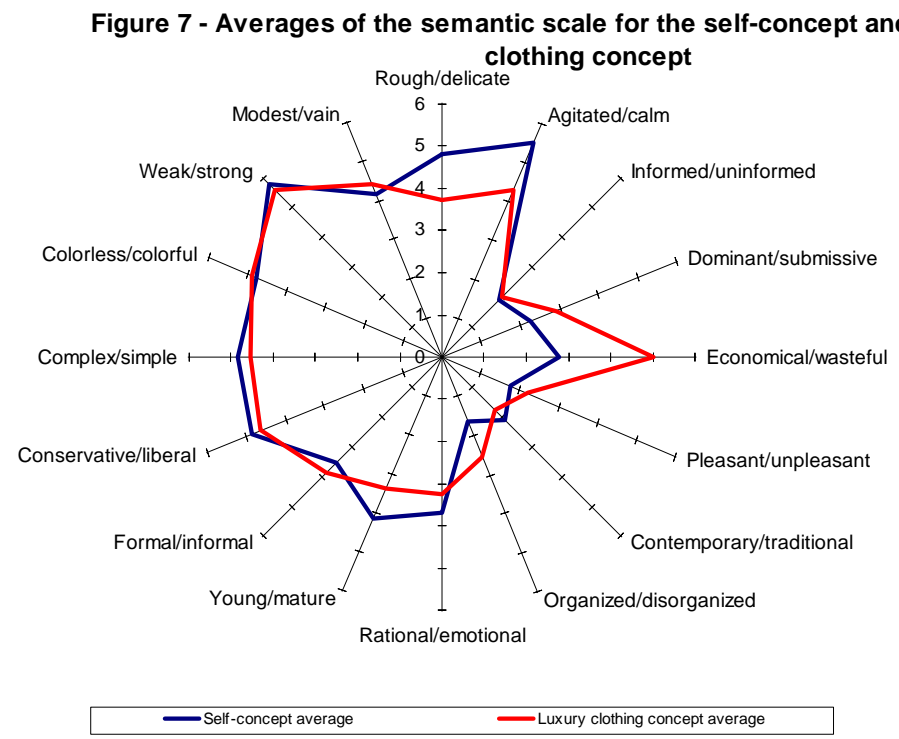

As for the discourse analysis from the interviews, it could be noticed - and demonstrated through excerpts from the interviews - that most of the male gays consume products that are directly related to their self-concept:

I have not yet achieved the status that I want. I'm at the beginning of a long journey. I'm looking forward to being a great lawyer. I want to be respected for my profession to such a point that my sexual orientation doesn't interfere anymore. Unfortunately, today, at 29 years old, I'm so far from it... (at this moment the interviewee mentioned some of the difficulties he goes through as a lawyer in Rio de janeiro). I believe that one of the best ways to minimize this gap between my self-concept (as a lawyer) and what I want to be is by wearing clothes that reflect my self-concept as a lawyer. One example is the fact that I only wear Hugo Boss suits, which is a brand that represents exactly who I want to be. (Interviewee \#.11) 
If I am or at least want to be (laughter) a well-informed person, certainly my favourite brand will also be. After all, if I wear an old-fashioned clothing brand, it would suggest that I am old-fashioned. Nowadays, my favorite brand is Forum (at this moment the interviewee insisted on showing the brand's logo printed on the pants he was wearing). I don't wear this brand just because it fits well. I wear Forum because it communicates a concept. It is a brand that is constantly reinventing itself. It has everything to do with me. (Interviewee \# 3)

I totally agree that part of my identity comes from the brands I use. After all, in my opinion, brand is not just about design, beauty... Brand is all about attitude and, as I choose to use certain brands, it is a sign that I am part of that group. In my opinion, when we are part of a group, we exchange references and these references will be part of our identity. (Interviewee \# 6)

Moreover, it was observed that, in several occasions, these subjects use differentiated products with high aggregate value as a mechanism to enable their membership in certain groups:

One of my favourite brands is AussieBum. This brand is awesome. I work out a lot, I take care of myself... I think I have everything to do with Aussie (laughter): I'm good-looking, strong, fit (/aughter).... just joking. AussieBum even has a community that I am part of. Not everyone can be a member of this select group... For that, besides wearing the brand you have to act consistently. (Interviewee \# 8)

When I'm working, I try to wear clothes that make me look like a successful person. For instance, I love Hugo Boss suits. In my mind, anyone who wears this brand is successful and, since this is my highest professional ambition, I always try to wear this brand. I think that in my profession (/awyer), image is very important and helps me to be part of a select group. (Interviewee \# 11)

In this research, we were able to identify clothing brands that act as an indicator of the interviewee's sexual preference, as well as to differentiate the interviewee among other gays. This confirms the position of Allérès (2000), Amui (2006) and Vigneron and Johnson (2004), when they point out that luxury goods, in addition to objective and subjective qualities -represented respectively by functionality and aestheticshave a symbolic dimension that needs to be considered:

In my opinion, Calvin Klein means power, status and success. Think with me: the person who wears this brand has to have a gorgeous body (the interviewee showed his well-shaped biceps), to occupy a privileged position, that is, needs to stand out in a group and, above all, to succeed both personally and professionally, because this is not a cheap brand. I wear it because I'm 25 years old, I feel good and my body is in its best shape, but Calvin Klein is not for everyone (laughter). (Interviewee \# 8)

I love brands. I like Hugo Boss, Aramis and Sandpiper, but the one I love is Calvin Klein. Their jeans make my body look great, the t-shirts are the best and I don't even need to comment on the eyeglasses. I feel great when I wear Calvin Klein. (Interviewee \# 11)

Another critical point taken from the discourse analysis of these interviewees is the fact that, in several occasions, their consumption of luxury products does not "compete" directly with their "self", and also that they prefer neutral brands when referring to clothing.

I enjoy working out, taking care of myself, I'm super vain. Because of that, some of my friends even call me Barbie $^{3}$ (laughter), but I'm not... I have a nice body and, to show it off, I prefer brands that are more discrete, that draw more attention to me rather than to the clothes. The brand Hering ${ }^{4}$ does it for me. I enjoy wearing tshirts, underwear, shorts... I like almost everything about this brand. It's funny because I know that I can find 200 people wearing a Hering t-shirt, but when I wear it, I feel different from the other 200 (at this moment, the interviewee tapped on his chest, as a sign of pride). I feel like I'm better than the others (/aughter). (Interviewee \# 7)

It is also noteworthy that the male gay self-image is partially constructed through the consumption of products from the luxury market, specifically through the consumption of particular luxury clothing brands that express their sexuality Therefore, it is possible to assert that the concept of self-image that the gay has about himself affects consumption as well as that the type of consumption influences the composition of this self-image. Here, again, the theory converged with the results of the research; after all, Belk (1988) defends the principle that the possessions of an individual are part of his identity. The author observed the relationship between these possessions and the human beings' sense of self and stated that this relation is a "two-way road": "We may impose our identities on possessions and possessions may impose their identities on us" (Belk, 1988, p. 141).

As I work for myself (referring to the fact of being self-employed), I can dress according to my style, to the way I think and act. And because I am an extremely liberal person, I dress this way. For example, there are days that I want to wear a cool outfit such as baggy pants, a big watch and a tight shirt; I put them on and that's it. You 
know, I can deal with it and if I have a liberal personality, I have to pay a price for it. I'm not going to hide behind a suit or a squared look. (Interviewee \# 1)

The observation of the results obtained from the application of the semantic scale showed that the means of self-concept and concept related to luxury clothing were particularly close to each other in the case of the informed/uninformed and conservative/liberal bipolar adjectives pairs. In the first case, this congruence was supported by the discourse of the majority of interviewees stating that they are very concerned about information, and that their way of dressing is directly related to it:

Gays face many forms of prejudice, right? Tell me you never saw a person pointing at a faggot? You have never been pointed? Well... a way to create barriers against this prejudice is to be informed, connected, and fashion is a reflection of that. Fashion is more than just clothes. It expresses a concept of who we are, and being welldressed is a sign that we are connected, informed. (Interviewee \# 10)

In regard to the colorless/colorful pair, most of the interviewees said that they enjoy being "colorful". They associated color with joy or brightness, and wore a particular clothing brand as a way to obtain these features:

When I wear Nike, I feel strong, handsome and powerful. This brand enlightens me. (Interviewee \# 5)

Regarding the adjectives pairs with lower congruences between self-concept and clothing concept, the economical/wasteful and agitated/calm pairs prevailed. Concerning the first adjective pair (economical/wasteful), the discourse analysis showed that most interviewees feel that they spend too much and would like to be more economical, while at the same time, they referred to their favourite brands as being less accessible. This paradox can be readily observed when the interviewees point out that they enjoy exclusivity, a feature that usually raises the price of the piece:

I didn't want to spend so much. I would like to learn how to control myself. There are times when I'm walking down the street and have to cross it to avoid falling into temptation, because it is very difficult. Now that I'm dating, it got worse. I have two reasons to spend. First, I need to dress well and second, as my boyfriend is young and also a model, whatever he wears looks great on him, so I end up buying things for him too. I know I shouldn't do that, but when I'm in love.... I lose control. (Interviewee \# 2)

In regard to the second adjective pair (agitated/calm), the divergence may be due to the difficulty the interviewees demonstrate in associating their clothes specifically to this type of behaviour:

I think that to be able to make this association I will have to think of a gay who wears Diesel, is it okay? It's easier to think that way... For instance, sometimes my boyfriend is very calm, but sometimes more agitated. So, in the case of Diesel, which he also loves, I will try to justify that it depends on the collection or style of that outfit. Diesel has clothes for partying, in which case I would consider agitated, but it also has basic shirts that we can wear every day, which could be considered calm. Did you understand my association? (Interviewee \# 8)

Therefore, in addition to having five dimensions - conspicuousness, uniqueness, quality, hedonism, and extended self - luxury goods, more than any other product, are purchased not for what they are, but for what they mean (Amui, 2006). Consequently, it can be concluded that luxury products directly influence the development of gays' self-concept.

\section{Final Considerations}

Having been a qualitative research, its results may not be generalized to the whole Brazilian gay population. Even so, this research showed that, in what refers to a better understanding of the fundamental values that guide luxury brand products consumption, for male gays - and probably for the general public these values involve status, the perception of exclusivity through the use of products that are differentiated and that have high aggregated value, and the possibility of participating in specific groups through the acquisition of some products.

This confirms the propositions of Allérès (2000), of Amui (2006) and of Vigneron and Johnson (2004), when they stressed that luxury products are represented both by their objective and subjective qualities respectively represented by funcionality and aesthetics - as well as by a symbolic dimension. Amui (2006) said that, more than any other product, luxurious items are bought not for what they are, but for what they mean, apart from having five dimensions: conspicuity, exclusivity, quality, hedonism, and the "me" extension. 
Although this research lacked the sophistication that could have brought a multidimensional approach of the self-concept, it is believed to have provided valuable contributions to the study of the male gay consumer behaviour, specifically in relation to their self-concept as an important factor influencing their choices regarding the consumption of luxury clothing. This study also contributed significantly to the development of marketing strategies aimed at this subgroup - proved to be capable of consuming in large scale. In other words, at the managerial level, this study offers interesting inferences for professionals concerned with brand positioning, as far as its personality is involved, as it elucidates the association between this personality and the self-concept dimensions.

At the academic level, we can say that the main contribution of this study to Marketing as a field in the science of Business Administration lies in the expansion of the limited available literature on this subject, since gays - and not only the male gays - have immense potential for consumption, although they had not been properly acknowledged by both the academic community and the market itself.

\section{Notas}

1- SPturis is a tourism and events company located in the city of São Paulo. One of its activities, is the research on topics related to the behavior of the Brazilian population, more specifically of that city.

2- It was assumed that the interviewees were honest in disclosing their true income.

3- Term used by gays to define a male gay who weightlifts or has a very muscular body.

4- The fact that the "Hering" brand was mentioned as a luxury brand by many respondents was initially surprising because, traditionally, this brand does not present a "luxury DNA". However, after questioning some of the respondents, it became clear that, due to its basic configuration, this brand does not "compete" with its consumer - i. e., it does not come before the consumer. And that, in the case of gays, is relevant because it can be assumed that they would be more interested than heterosexuals in showing their bodies as an indicator of what they are.

\section{Referências}

Allérès, D. (2000) Luxo...estratégias, marketing. Rio de Janeiro: FGV.

Amui, I. C. (2006) Comportamento do consumidor de cosméticos de luxo: um estudo exploratório. 2006. 112 f. Dissertação (Mestrado em Administração) - Universidade Federal do Rio de Janeiro, Rio de Janeiro.

Baudrillard, J. (1973) O sistema dos objetos. São Paulo: Perspectiva.

Baudrillard, J. (1981) A sociedade de consumo. Lisboa: Edições 70.

Belk, R. (1988) Possessions and the extended self, Journal of Consumer Research, 15, 139-168.

Bourdieu, P. (1981) Distinction: a social critique of the judgement of taste. Cambridge: Harvard University Press.

Bourdieu, P. (1983) Gosto de classe e estilos de vida. In Ortiz, R. (Org). Pierre Bourdieu: Sociologia. São Paulo: Ática.

Bowes, J. E. (1996) Out of the closet and into the marketplace: meeting basic needs in the gay community. In Wardlow, D. L. (ed.) Gays, lesbians, and consumer behaviour: theory, practice, and research issues in marketing. New York: Harrington Park, p. 219-244.

Campos, R., Suarez, M. \& Casotti, L. (2005) Possibilidades de contribuição da sociologia ao marketing: itinerários de consumo. Paper presented at II Encontro de Marketing da ANPAD. Rio de Janeiro.

Carrieri, A. De P.; Sarsur, A. M. Percurso semântico do tema empregabilidade: um estudo de caso em uma empresa de telefonia. Paper presented at XXVI Encontro Nacional de Programas de Pós-Graduação em Administração, Salvador.

Castarède, J. (2005) O luxo - os segredos dos produtos mais desejados do mundo. São Paulo: Barcarolla.

Cavallet-Mengarelli, A. P. R. (2008) Interações entre autoconceito e personalidade da marca nas representações de consumo de adolescentes. 187f. Dissertação (Mestrado em Administração) Universidade Federal do Paraná. Curitiba. 
Chaplin, L. N. \& John, D. R. (2005) The development of self. Brand connections in children and adolescents. journal of Consumer Research, 32, 119-129.

Constâncio, J. R. (2007) Branding e mercado GLS: um encontro de valor. Paper presented at Simpósio Brasileiro de Gestão de Negócios Portuários, Santos.

Csikszentmihalyi, M. (2000) The costs and benefits of consuming, journal of Consumer Research, 27.

D’Angelo, A. C. (2004) Valores e significados do consumo de produtos de luxo. 209 f. Dissertação (Mestrado em Administração) - Universidade Federal do Rio Grande do Sul. Porto Alegre.

Deloizer, M. W. \& Rodrigue, J. (1996) Marketing to the homossexual (gay) market: a profile and strategy implications. In Wardlow, D. L. (ed.) Gays, lesbians, and consumer behaviour: theory, practice, and research issues in marketing. New York: Harrington Park, p. 203-212.

Doron, R. \& Parot, F. (1998) Dicionário de psicologia. São Paulo: Ática.

Escalas, J. E. \& Bettman, J. R. (2005a) You are what they eat: the influence of reference groups on consumers' connections brands. Journal of Consumer Psychology. 13 (3), 339-348.

Escalas, J. E. \& Bettman, J. R. (2005b) Self-construal, reference groups, and brand meaning. Journa/ of Consumer Research. 32.

Faria, A. A. M. de. Sobre germinal: interdiscurso, intradiscurso e leitura. 2001. Tese (Doutorado em Lingüística) - Universidade de São Paulo, São Paulo.

Faria, A. A. M.; Linhares, P. T. F. S. O preço da passagem no discurso de uma empresa de ônibus. In Machado, I. L. (Org.). Análises de discursos: sedução e persuasão. Belo Horizonte, NAPq Fale/UFMG, 1993. (Caderno de Pesquisa, 13).

Gaskell, G. (2004) Entrevistas individuais e grupais. In: Bauer, M. W. \& Gaskell, G. Pesquisa qualitativa com texto, imagem e som- um manual prático. 3. ed. Petrópolis: Vozes.

Grubb, E. L. \& Grathwhohl, H. L. (1967) Consumer self-concept, symbolism and market behaviour: theoretical approach. Journal of Marketing. 31.

Haie, V. (2002) Donnez-nous notre luxe quotidien. Paris: Gualino.

Hawkins, D. L., Mothersbaugh, D. L. \& Best, R. J. (2007) Comportamento do consumidor: construindo a estratégia de marketing. Rio de Janeiro: Elsevier.

Hirschman, E. (1986) Humanistic Inquiry in marketing research: philosophy, method and criteria. Journal of Marketing Research, 32.

Hirschman, E. \& Holbrook, M. (1982) Hedonic consumption: emerging concepts, methods and propositions. journal of Marketing, 46 (3), Summer

Holbrook, M., Block, L. \& Fitzsimons, G. (1996) Personal Appearance and Consumption: a framework for descriptive and prescriptive analysis. Consumption, Markets and Culture, $2(1), 1-55$.

IBGE - Instituto Brasileiro de Geografia Estatística. (2007) Disponível em: <http://www.ibge.gov.br>. Acesso em: jan. 2008.

Ipsos Marplan (2006) Disponível em: http: <www.ipsos.com.br> . Acess in feb.2008.

Kates, S. M. (1998) Twenty million new customers! Understanding gay men's consumer behaviour. New York: Harrigton Park.

Kubo, A. T. V. Aspectos do discurso jornalístico sobre a luta pela terra. 2003. Dissertação (Mestrado em Estudos Lingüísticos - Análise do Discurso) - Universidade Federal de Minas Gerais, Faculdade de Letras, Belo Horizonte.

Lipovetsky, G. \& Roux, E. (2005) O luxo eterno: da idade do sagrado ao tempo das marcas. São Paulo: Cia das Letras.

Lukenbill, G. (1999) Untold Millions: secret truths about marketing to gay and lesbian consumers. New York: Harrington Park Press.

Malhotra, N. K. (1981) A scale to measure self-concepts, person concepts, and product concepts. Journal of Marketing Research, publicado pela American Marketing Association; reimpresso com permissão, nov., p.462.

McCracken, G. (1986) Culture and consumption: a theoretical account of the structure and movement of the cultural meaning of consumer goods. Journal of Consumer Research, 13.

Miranda, A. P. C. (1998) Comportamento de Consumo em Vestuário de Moda Feminina: Análise Exploratória. Dissertação de Mestrado em Administração de Empresas, Universidade Federal do Paraná. 
Nunan, A. (2003) Homossexualidade: do preconceito aos padrões de consumo. Rio de Janeiro: Caravansarai.

Rocha, E. (1984) O que é etnocentrismo. São Paulo: Brasiliense.

Rocha, E. (1995) Sociedade do sonho: comunicação, cultura e consumo. Rio de Janeiro: Mauad.

Reed II, A. (2002) Social Identity as a useful perspective for self-concept-based consumer research. Psychology \& Marketing, $19(3), 551-564$.

Richins, M. L. (1991) Social comparison and the idealized images of advertising. Journal of Consumer Research, 18.

Rosenberg, M. (1979) Conceiving the Self. New York: Basic Books.

Ross, I. (1971) Self-concept and brand preference. Journal of Business of the University of Chicago, 44 (1).

Schenk. C. T. \& Holman R. H. (1980) A Sociological Approach to Brand Choice: The Concept of Situational Self-Image. Advances in Consumer Research. 7, 610-614.

Sirgy, M. J. (1982) Self-concept in consumer behaviour: a critical review. Journal of Consumer Research, 9 (3).

Sivadas, E.; Machleit, K.A. A scale to determine the extent to object incorporation in the extended self. In: Park, C. W.; Smith, D. C. (ed.). Marketing theory and applications, 5, Chicago: American Marketing Association, 1994.

Slater, D. (2002) Cultura do consumo e modernidade. São Paulo: Nobel.

Soares, J. C. (2000) O Dinheiro Que Ousa Dizer o se Nome: o Mercado GLS e suas repercussões. 2000.96 f. Monografia de Conclusão de Curso. UFF, Departamento de Comunicação Social, Rio de Janeiro.

Solomon, M. (1983) The role of products as social stimuli: a symbolic interactionism perspective. Journal of Consumer Research, $10(3)$.

Solomon, M. (2002) O comportamento do consumidor: comprando, possuindo, sendo. 5. ed. Porto Alegre: Bookman.

SPTuris (2007). Documento interno da empresa. Acess in march 2007.

Twitchell, J. (2000) In defense of materialism. Across the board, March.

Veblen, T. (1899) A Teoria da Classe Ociosa. New York: MacMillan.

Vigneron, F. \& Johnson, L. (2004) Measuring perceptions of brand luxury. Journal of Brand Management, 11 (6), 484-506.

Wattanasuwan, K. (2005) The self and symbolic consumption. The Journal of American Academy of Business, $6(1), 179-184$. 